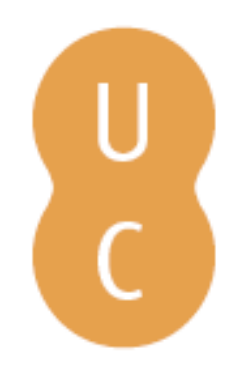

\title{
pompalina
}

\section{Quality as politics and as policies and the importance of instruments}

\author{
Autor(es): $\quad$ Veiga, Amélia; Magalhães, António \\ Publicado por: Imprensa da Universidade de Coimbra \\ URL \\ persistente: \\ URI:http://hdl.handle.net/10316.2/46341 \\ DOI: \\ DOI:https://doi.org/10.14195/978-989-26-1620-9_2
}

Accessed : $\quad$ 26-Apr-2023 12:05:10

A navegação consulta e descarregamento dos títulos inseridos nas Bibliotecas Digitais UC Digitalis, UC Pombalina e UC Impactum, pressupõem a aceitação plena e sem reservas dos Termos e Condições de Uso destas Bibliotecas Digitais, disponíveis em https://digitalis.uc.pt/pt-pt/termos.

Conforme exposto nos referidos Termos e Condições de Uso, o descarregamento de títulos de acesso restrito requer uma licença válida de autorização devendo o utilizador aceder ao(s) documento(s) a partir de um endereço de IP da instituição detentora da supramencionada licença.

Ao utilizador é apenas permitido o descarregamento para uso pessoal, pelo que o emprego do(s) título(s) descarregado(s) para outro fim, designadamente comercial, carece de autorização do respetivo autor ou editor da obra.

Na medida em que todas as obras da UC Digitalis se encontram protegidas pelo Código do Direito de Autor e Direitos Conexos e demais legislação aplicável, toda a cópia, parcial ou total, deste documento, nos casos em que é legalmente admitida, deverá conter ou fazer-se acompanhar por este aviso. 
Cristina Pinto Albuquerque Ana Maria Seixas

Albertina Lima Oliveira

António Gomes Ferreira

Maria Paula Paixão

Rui Paquete Paixão COORDS

\section{HIGHER}

EDUCATION

AFTER

BOLOGNA

Challenges and Perspectives 


\title{
CHAPTER 2
}

\section{QUUALITY AS POLITICS AND AS POLICIES AND THE IMPORTANCE OF INSTRUMENTS}

\author{
Amélia Veiga \\ Centro de Investigação e Intervenção Educativas, \\ Centro de Investigação de Políticas do Ensino Superior e Faculdade \\ de Psicologia e de Ciências da Educação da Universidade do Porto.
}

\section{António Magalhães}

Centro de Investigação de Políticas do Ensino Superior e Faculdade de Psicologia e de Ciências da Educação da Universidade do Porto.

This chapter aims at contributing to understand the development of European higher education quality assurance politics and policies. Drawing on discursive institutionalism, it analyses policy documents (reports, recommendations and guidelines) on quality assurance issued by institutions at the European level underlining the role of ideas in the construction of quality as a political driver. The argument is that the principles construing the politics of quality assurance at the European level are being diluted in the enactment of quality assurance policies, practices and their instruments. This is a case of 
goal displacement with regard to the major political objective of a more integrated higher education in Europe. Discursive institutionalism allowed identifying the role of normative and cognitive ideas in the shift from the centrality of ultimate political values to instrumental ideas reflecting proceduralism. This shift illustrates the process of goal displacement of quality assurance policies coordinated at the European level.

\section{Introduction}

Quality assurance is an enduring topic in the construction of the European Higher Education Area (EHEA). The European dimension of quality assurance is visible in the European level dynamics developed since the 1990s. European quality assurance policy is an instrument of European governance as it relies on the interaction of policies at the institutional, national and European levels. In this sense, a common grammar has been developed privileging accreditation to ensure coherence to evaluation policies (Magalhães, Veiga, Ribeiro, Sousa, \& Santiago, 2013). However, from the perspective of the European Commission (2009), the membership of higher education quality assurance agencies in ENQA (European Association for Quality Assurance in Higher Education) and their registration in the EQAR (European Quality Assurance Register for Higher Education) is not fulfilling the objectives of encouraging mobility as is one of the aims of European cooperation in the fields of education and training. In order to deal with this goal displacement (Hood, 2000), European Standards and Guidelines (ESG) for quality assurance were revised in 2015 with the explicit aim of improving readability and user-friendliness of quality assurance systems. 
Goal displacement occurs when major goals initially defined are replaced in favour of new goals in the political process. Quality as a political driver of European coordination of higher education area aims at consolidating the EHEA on the basis of comparative quality and it is translated into policy goals focusing the promotion of mobility. This translation of the politics (consolidation of EHEA) into policy (mobility policies) may result into goal displacement as "an instrumental value becomes a terminal value in a way that defeats the objective" (Hood, 2000, p. 214).

This the case of quality assurance politics and policies developed within the EHEA as efforts towards convergence of procedures are lagging behind European values and principles. The argument is that the principles construing the politics of quality assurance are blurred in the enactment of quality assurance policies. Quality assurance practices and their instruments become the ultimate value hindering the major political objective of a more integrated higher education in Europe. The literature on policy instruments underline precisely that the instruments used to serve a policy impinge on the nature of the policy itself (Lascoumes \& Galès, 2007).

With the purpose of understanding the European higher education politics and policies of quality assurance we will draw on discursive institutionalism to underline the role of ideas in the construction of quality as a political driver. Policy documents (reports, recommendations and guidelines) on quality assurance issued by institutions at the European level were analysed to characterize the political enactment of quality assurance policies.

In the first part of the chapter, we will identify the discourses or system of meaning that constitute the identity of the politics of quality. In the second part we will use Schmidt's distinction between normative and cognitive ideas to analyse the construction 
of European quality assurance politics and policy. Quality standards are the core instrument for comparative quality and are used as a reference for internal and external quality assurance systems in higher education and for the registration of quality assurance agencies that comply with the ESG (European Commission, 2009). The aim is to grasp the ends/means reversal in the ESG definition (2005) and their revision (2015) of quality standards of the EHEA.

\section{Ideas Matter}

Ideas are embedded in political action and discursive institutionalists (Schmidt, 2008) ascribe to them the role of constituting political action. This is not to deny that institutional frameworks play a role in the production and the dissemination of ideas (Mehta, 2011).

Ideas are located at different levels and ideas convened by public philosophies or Zeitgeist, ideas about problem definitions and ideas about problem solutions (Kingdom, 1984; Mehta, 2011) contain normative and cognitive ideas (Schmidt, 2008). Normative ideas are those that "attach values to political action and serve to legitimate the policies in a program through reference to their appropriateness (see March and Olsen 1989)" (Schmidt, 2008, p. 307) and cognitive ideas "provide the recipes, guidelines, and maps for political action and serve to justify policies and programs" (Schmidt, 2008. p. 306). While the former uses principles and values to legitimate social compliance to policies and programmes (e.g. quality of higher education), the latter provides taken-for-granted assumptions on political procedures that justify political action (e.g. evaluation of quality).

Public philosophies drive normative ideas that tend to dominate policies. They are meta-ideas providing "a heuristic 
that tells political actors what aspects of the issue to emphasize and what side to take" and function "as a kind of changing cultural touchstone to which actors can appeal in their efforts to advocate for a particular policy or symbol" (Mehta, 2011, p. 42). In turn, the role of ideas in shaping problem definition and ideas shaping problem solution promote chiefly cognitive ideas. While the latter provides the means for solving the problem and accomplishing policy objectives, the former configures policy responses "that will seem desirable, and hence much of political argument is fought at the level of problem definition" (Mehta, 2011, p. 27).

Public philosophies function as metanarratives and are embedded in political actors and "operate at a presuppositional level of social science epistemology or beyond our awareness" (Somers \& Gibson, 1996, p. 63). This is the case of 'knowledge society' as an ideograph shaping politics and of 'quality' as one of its elements. Actually, quality is construed as a value on the basis of ideas configuring policy responses and providing the means for solving the problem. In spite of the fact that quality became a keyword in structuring political action, it assumes the features of an 'empty signifier'. Discourse analysists define this type of signifier as 'pure' as it possesses consensual subjective or ideal value. In this sense, quality is subjectively associated with which is good and worth to pursue within the 'knowledge society'.

From our perspective, quality as a normative idea prevails in the translation of public philosophies into policies as it is referred to a desirable and unquestionable value. Already in the 1990s, Barnett referring to the UK experience, distinguished between 'enlightenment' and 'surveillance' purposes in quality assurance questioning the consensual desirability of quality. The author underlined that the meaning of quality was contingent to the development of instruments to evaluate it. In this regard, 
evaluation of quality plays the role of the definition of the policy problem and its solution. On the one hand, evaluation of quality appears discursively as a means to solve the problem of comparative quality associated with the political goals (e.g. increasing mobility); on the other hand, evaluation of quality frames policy solutions relying, for instance, on accreditation. Hence, evaluation of quality as an instrument affect the meaning of quality assurance practices. These instruments developed on the basis of a technicist approach that reduce "the possibility of evaluation having hermeneutic or dialogic value within the academy and which could enable the academic members of the higher education system to become more genuinely a professional community" (Barnett, 1994, p. 165).

The instrumentality of evaluation with regard to quality challenged the prevalence of normative ideas of quality and its statute of an 'empty signifier' as its meaning is being struggled for by competing discourses, in Barnett's terms: 'enlightenment' versus 'surveillance'. Guy Neave (2012) attributed to quality assurance procedures a key role in the development and workings of the 'Evaluative state' underlining the 'surveillance' purposes of quality assurance policies at the European, national and institutional levels. This proceduralist and technical approaches to quality assurance has been assuming a problemsolving perspective that fails to recognize its influence on the reconfiguration of the idea of quality in shifting from normative to cognitive nature. This is a major ingredient for turning quality into a means rather than a goal in itself.

Arguably, ideas matter as they contribute to understand how politics and policies of quality on higher education turn into instrumental and procedural approaches. Following from discourse theorists, articulation is "any practice establishing a relation among elements such that their identity is modified 
as a result of the articulatory practice" (Laclau \& Mouffe, 1985, p. 105) and will be useful to understand how the struggle over the meaning of quality revolves around normative and cognitive ideas.

\subsection{The role of ideas in constituting action}

In the establishment of the EHEA the prominence of cognitive ideas relies on the link established between quality assurance and the enhancement of mobility to further European integration. The statute of ideas as either explanans (the explanation) or explanandum (what needs to be explained) (Mehta, 2011) reveals key dimensions at work in policy action. When scrutinizing 'why European cooperation in quality should be promoted?' 'because quality is a undeniable need' - 'quality' appears as playing simultaneously the role of the explanandum and of the explanans for cooperation. As explanans it assumes a normative stance legitimizing cooperation and as explanandum quality is diluted into a cognitive approach based on practices and instruments. These practices and instruments were created and legitimized by the value of quality and justified on the basis of their feasibility.

In the EHEA, European Standards and Guidelines (ESG) reflect this pragmatic policy approach and as a policy instrument they influence the nature of quality as a politics and as a policy. Actually, as argued by Guy Neave the focal points in the politics of quality are determined by the evaluation agencies which "are, par excellence, the arena where 'politics of quality' are fought out and laid down" (Neave, 1994, p. 129). The fact that evaluation of quality is put in the hands of external and bureaucratic power dilutes the normative nature of quality in the cognitive stance of its instrumentality. 
For the purpose of understanding the risks of seeing quality from an instrumental and procedural perspective into detriment of its major normative assumptions, it is of utmost importance to find out where the power lies. The power relationships develop in the tension between education as a national prerogative and the interest of European institutions in promoting a more integrated political action. Under this framework, higher education institutions are deemed to be in control of quality assurance of their activities.

Driving the shift from normative to cognitive ideas is these power relationships between the European, national and institutional levels of policy action. Barnett underlines that there are quality processes and structures falling under the control of the academic community and those that "come to the control of agencies external to academe" (Barnett, 1994, p. 172). And Amaral adds that "European higher education is in a kind of schizophrenic situation, as on the one hand there is a rhetoric of promotion of cooperation, trust and the European dimension and, on the other hand, quality mechanisms are apparently based on suspicion" (Amaral, Tavares, \& Cardoso, 2011, p. 2).

On the basis of these power relationships the analysis of the politics must take into account the mandate addressed to quality, the capacity to materialize this mandate and the influence of the instruments in driving politics making the case of the importance of ideas in construing political action in the field of quality assurance.

\section{Mandate addressed to quality}

Ideas driven by the European Commission with regard to quality captured by the centrality of cooperation between member states to reinforce mobility in higher education as a value 
and a principle. In the 1991 Memorandum on Higher Education in the European Community (1991) European excellence was articulated with quality of higher education on the basis of the assumption that public expenditure "makes assurance of quality a necessary part of political accountability" (European Commission of the European Communities, 1991, p. 13). At the same time, mutual recognition is articulated with comparative quality opening the way to

Quality viewed as a larger issue than comparison within and between Member States and that the potential for exchange of experience and for the cooperation at Community level in the determination of the parameters of quality and in their assessment be exploited as fully as possible (European Commission of the European Communities, 1991, p. 14).

The subsequent initiatives at the European level articulated mutual recognition with cooperation for the reinforcement of mobility in higher education (Conclusions of the Council and the Ministers of Education meeting within the Council of 25 November 1991 (91/C 321/03) and the transparency of national quality assurance systems in higher education with cooperation in quality assurance (Council Recommendation of 24 September 1998 on European cooperation in quality assurance in higher education / 98/561/EC).

The mandate addressed to quality, as reflected in the 1998 Council Recommendation on European cooperation in quality assurance in higher education (98/561/EC), set the foundations of a European network of national quality agencies (ENQA). The articulation between quality and principles such as 'accountability', 'mutual recognition', 'comparative quality', 
'cooperation', and 'transparency' drove the definition of the ESG. These articulations legitimize the function and the structure of the European dimension of quality assurance for the EHEA.

The meanings of quality were fixed by a managerial perspective underlying a technical approach on the basis of the association between 'quality' and 'accountability', 'comparative quality' and 'transparency'. In turn, the articulation between 'quality' and 'mutual recognition' and 'cooperation' promote ideas about problem-definition and political arguments in favour of 'cooperation' are fought for at this level. The problem of 'mutual recognition' is contingent to 'quality' and it is to be dealt with by means of 'cooperation'. However, these articulations also trigger ideas about problem-solutions ascribing to cognitive ideas an important role in the reconfiguration of quality. In this sense, the problem definition of mutual recognition is associated with the existence (or not) of quality being 'cooperation' a key mean to this end.

This tendency to deprive quality of normative meanings culminates with the acknowledgement that "since 2005, considerable progress has been made in quality assurance as well as in other Bologna action lines such as qualification frameworks, recognition and the promotion of the use of learning outcomes, all these contributing to a paradigm shift towards student-centred learning and teaching”. (ENQA, 2015, p. 3).

These achievements are then presented as ideas about problem-solutions justifying cognitive ideas with vested interests. However, the articulations between 'quality assurance', 'quality frameworks', 'recognition' and 'learning outcomes' are cognitive ideas shaping simultaneously problem-definition and problemsolution in dealing with the paradigm shift towards studentcentred learning and teaching. In this sense, the cognitive ideas about quality, as argued before, promoted 'quality' as 
playing simultaneously the role of the explanandum and of the explanans, in this case not for cooperation, rather endorsing student-centred learning and teaching approaches. As explanans it assumes a normative stance legitimizing the paradigm shift; as explanandum quality is diluted into a cognitive approach based on 'quality assurance', 'quality frameworks', 'recognition' and 'learning outcomes' procedures. These ideas reconfigure the mandate addressed to 'quality' underlining instruments justified on the basis of their practicability. Actually, drivers for a revised ESG version are to be found on the need "to improve their clarity, applicability and usefulness, including their scope" (ENQA, 2015, p. 3) reiterating justifications for political action.

Normative ideas attaching values to political action faded away as 'cooperation' or 'mutual trust' are not seeing as worthy to pursue by themselves, they essentially have a meaning in articulation with the development of procedures. The idea of 'cooperation' appears associated with the idea of team work "with other institutions, quality assurance agencies and the national ENIC/NARIC centre with a view to ensuring coherent recognition across the country" (ENQA, 2015, p. 10) and ESG purposes and principles limit themselves to reinforce "mutual trust, thus facilitating recognition and mobility within and across national borders" (ENQA, 2015, p. 6). In this sense, appropriate recognition practices are dependent on proceduralism permeating institutional processes. Ideas convened by public philosophies or Zeitgeist around the principle or value of student-centred learning and teaching also reflect the dominance of the cognitive approach about the design and delivery of study programmes and the assessment of learning outcomes (standard 1.2 - Design and approval of programmes) and "flexible modes of learning and teaching, are taken into account when allocating, planning and providing the learning resources and student support" (ENQA, 2015, p. 11). 


\subsection{Endeavouring the mandate addressed to quality}

The political goal of contributing to the 'common understanding' of quality assurance is articulated with teaching and learning across borders (space) and among stakeholders (ESG, 2015). The idea that 'common understanding' makes possible common quality assurance practices is a normative idea legitimating the definition and use of ESG. In this sense, the ESG are deemed to provide "actors with common 'reference points' that orient and make sense out of their interactions" (Glynos \& Howarth, 2007, p. 58). At the same time, the terms in which ESG are expressed bring forward their instrumentality in pursuing policies associated with increasing "transparency, thus helping to build mutual trust and better recognition of their qualifications, programmes and other provision" (ENQA, 2015, p. 4) and in "a broader context that also includes qualifications frameworks, ECTS and diploma supplement that also contribute to promoting the transparency and mutual trust in higher education in the EHEA" (ENQA, 2015, p. 4).

At the national level, governments and evaluation agencies assume that ESG are promoting transparency, mutual trust and better recognition. However, these normative ideas develop in the tension between education as a national prerogative and the interest of European institutions in promoting a more integrated political action. At the same time, cognitive ideas drive policy responses and political arguments at the level of problem definition and bring to the fore European and national interests and their conflicts.

ENQA aims at functioning as a European policy forum for developing and proposing standards, procedures and guidelines on quality assurance and finding common points of convergence between European quality assurance systems. At the national 
level these ideas feeding accreditation policies dilute in 'purposes' and 'improvement', 'enhancement', 'monitoring' and 'control' of quality of higher education. In this sense, quality tends to be dealt from a managerial perspective driven by these cognitive ideas.

Actually, following from the review of the Portuguese quality assurance practices the recommendations by ENQA in 2006 were to combine accreditation with institutional academic audit and to establish a strong independent national agency for quality assurance while underlining that "the legal framework should be formulated in a way that allows a certain degree of flexibility in the development and operation of the agency, e.g. determination of standards, adjustments in procedures, etc." (ENQA, 2006, p.10). The emphasis on flexibility of operationalisation is seen as a doorway to the fulfilment of ESG by national agencies making the issue of the distribution of power relationships problematic as there is a need to comply with European standards and guidelines. Actually, national quality assurance agencies that apply for inclusion in the European Quality Assurance Register (EQAR) undergo an external review for which the ESG provide the criteria. ENQA also relies on compliance with the ESG when it comes to granting quality assurance agencies full membership status (ENQA, 2015). Significantly, at the same time, the review of the Portuguese system underlined that the "consequences of accreditation and follow-up procedures in connection with academic audit should be clearly defined in the legal framework, and the agency should be responsible for providing the higher education institutions with proper information concerning the practical implications" (ENQA, 2006, p. 10). However, to be part of the European quality club the agencies should to continue actively support the fulfilment of ESG in higher education institutions. 
The mandate addressed to quality is driven by the European institutions that subsume national and higher education institutions by pragmatically promoting the quest for quality. In spite of the fact that ESG are controlled by the national evaluation agencies, there is an uneven distribution of power between European and national institutions. It is rather complex to retain a sense of the "collective or public arena that takes you beyond the narrow machinations of the political elite" (Stoker \& Marsh, 2010, p. 8) as the institutions involved in endeavouring the mandate addressed to quality are representatives of European quality assurance agencies (ENQA, ESU, EUA, EURASHE) of higher education institutions' leaderships (EUA), of students (ESU) and of stakeholders (Education International (EI), BUSINESSEUROPE). The issue of representation of interests comes to the fore as there is the need to find ways favouring a more inclusive and fair representation of interests. Actually, politics refers to power relationships that bring forward "the manner in which we constantly constitute the social in ways that exclude others" (Phillips \& Jørgensen, 2004, p. 36) and to the interests of the academic communities, the state and the market (de)regulation, one must add the one of the European institutions.

2.2. Instruments carrying out the mandate addressed to quality

EU institutions have been promoting the idea of better governance through the enhancement of participation of the interests involved in the mandate addressed to quality. The literature on governing and governance refers to the 'governance turn' and the "official adoption of 'governance semantics' in 2001" (Kjaer, 2010, p. 1) in the European political coordination implying that closer integration is to be achieved on the basis 
of enhanced political coordination. In this sense, the Open Method of Coordination (OMC) has evolved around this turn in the EU and it is the main instrument carrying out the mandate addressed to quality in higher education. On the one hand, normative ideas legitimating its adoption are to be found on the assumptions of 'democratic institutions' and the 'representation of the people'. These ideas "must try to connect Europe with its citizens. This is the starting condition for more effective and relevant policies" (European Commission, 2001, p. 4). To these type of ideas, one can add principles such as 'voluntarism', 'subsidiarity', and 'flexibility'.

On the other hand, cognitive ideas justifying the OMC on the basis of the need of 'co-operation', 'best practices', 'common targets' and 'guidelines' articulate with the 'regular monitoring' of progress. This articulation supports the enhancement of the European Commission in playing "an active co-ordinating role already and is prepared to do so in the future, but the use of the method must not upset the institutional balance nor dilute the achievement of common objectives in the Treaty" (European Commission, 2001, p. 21). Since 2000, the EU consolidated as a political system underlining the existence of European governance. This system consists of the political management of rule, both formal and informal, driving values and norms affecting behaviours and attitudes of actors (Hall \& Taylor, 1996; Kjaer, 2010).

Under this framework, political coordination of higher education has been promoting discourses basing, for instance, the evaluation common grammar to guarantee consistency in higher education policies (Magalhães et. al., 2013). This common grammar articulates normative ideas of quality with cognitive ideas associated with 'accreditation'. The primacy given to 'accreditation' as a privileged instrument of evaluation of 
quality, the dissemination across Europe of independent quality assurance and accreditation agencies are a result of European governance strategy. The EC sees the proliferation of quality assurance agencies across Europe as "a marked success as most countries have indeed set up a quality assurance system and European cooperation in the quality field has been intense" (European Commission 2004, p. 7).

Key in the development of the evaluation common grammar is ENQA, which is considered by the European Commission a "concrete outcome at European level and as a starting point (...) for future developments" (European Commission, 2004, p. 5) as much as it was determinant in drafting of the ESG. The centrality of ENQA in the governance of quality policies has assumed 'accreditation' as a cognitive idea. Furthermore, this feature and its pragmatic characteristics were enforced going beyond the role of national and higher education institutions. Actually,

although none of the successive communiques from the meetings of the Ministers of Education (Prague, Berlin, Bergen) gives primacy to accreditation, and although the Recommendation of the European Parliament and of the Council (2006/143/EC) of 15th January 2006 refers to both quality assurance agencies and accreditation agencies, the fact [is] that accreditation has been pushed forward against the opposition of a large number of higher education institutions [...] (Sarrico, Rosa, Teixeira, \& Cardoso, 2010, p. 39).

This makes visible the power imbalance within European governance actors and institutions in carrying out the mandate addressed to quality. However, and contrary to what the European level institutions, aimed at, European governance is not generating 
the desired levels of mutual trust. On the one hand, the opposition of higher education institutions was disregarded but, on the other hand, they were expected to actively work "to establish coherent internal quality assurance systems and align them with external assessment procedures" (European Commission, 2009, p. 4). This power imbalance is translated into the hegemony of cognitive ideas feeding pragmatism and proceduralism making quality policies as problem definition and problem solution issues.

So far, according to our argument, the mandate addressed to quality, the processes of endeavouring the mandate and its instruments show that there is the prevalence of cognitive ideas over normative ideas. Pragmatic and procedural approaches to quality while underlining the importance of the instruments impinge on the nature of the politics of quality itself. This entails a political goal displacement, as the instruments (accreditation structures and procedures) become a value by themselves shifting away from the initial political objective, i.e. the consolidation of the EHEA. Furthermore, quality itself is diluted in the instruments and procedures used to evaluate it.

2.3. Policies of quality: problem definition, problem solving, and the legitimacy by instruments

While the evaluation of quality is a contested terrain, the European institutions further enhanced the coordination of policies of quality underlining the priority of ideas about problem solution and problem definition, rather than ideas than normative ideas about European cooperation, citizenship, democracy, and participation.

The centrality of a pragmatic and instrumental centred approach to quality policies in Europe is visible in the 2009 report where 
the normative stances of the political endeavour are practically absent with regard to recognition and trust. On the contrary, recognition is articulated with 'quality assurance infrastructure', 'transparency for users and the society', 'sufficient level of comparability', 'cooperation with the NARIC-ENIC network is likely to enhance the database's potential', 'conventions of mutual recognition', 'portability of national accreditation'. In turn, trust is articulated with 'public access to the assessments made by the agencies' making them "transparent and trustworthy for European citizens and employers as well as for students and scholars from other continents" (European Commission, 2009, p. 3).

Along with these lines, the 2014 report on the progress in quality assurance in higher education the normative idea of transparency was diluted into the development of tools such as learning outcomes, qualifications frameworks, the European Credit Transfer and Accumulation System (ECTS), and the Diploma Supplement. In turn, the normative idea of an 'European area' is translated into an European area of skills and qualifications, contributing to the pragmatic approaches of policies for teaching and learning. The same goes with regard to trust as it is expected to be enhanced by 'quality assurance mechanisms' (European Commission, 2014) such as the publication of the results of quality evaluation.

Problem definition and problem solution are gathered in this instrumental approaches to quality policies. Actually, the problem of building "a higher level of trust between agencies" is dealt with the "need to convince their European peers that they offer a sufficient level of comparability". To this end, ideas about problem solution come from quality assurance infrastructures that must provide reliable data and proof of comparable practices as "a precondition for cross-recognition of degrees and the promotion of student mobility" (European Commission, 2009, p. 10). This 
represents an ends/means reversal where the initial political goals of social equity among European citizens is captured by the instruments developed for the purpose. With regard to trust, the problem definition matches the problem solution as "publishing QA results stimulates quality enhancement and helps build trust and transparency" (European Commission, 2014, p. 5).

This shift from normative goals to the centrality of instruments is made evident in the revision of the ESG held in 2015. On the basis of an assumed "consensus among all the organisations involved on how to take forward quality assurance in the European Higher Education Area" the revision takes on that the "engagement with quality assurance processes, particularly the external ones, allows European higher education systems to demonstrate quality and increase transparency, thus helping to build mutual trust and better recognition of their qualifications, programmes and other provision" (ENQA, 2015, p. 4).

On the one hand, higher education institutions are supplied with a more efficient framework for evaluating quality and, on the other hand, the EQAR can use it to register the quality assurance agencies as they comply with the ESG.

On the basis of the revision was the definition of the problem related to the need of enhancing 'innovation', 'economic growth and global competitiveness', 'skills and competences', 'flexible learning paths and recognizing competences', 'diversification of modes of educational provision', 'development of national and institutional quality assurance systems' (ENQA, 2015). Quality is introduced as an objective to be dealt with and these instruments appear simultaneously as the problem definition and solution. The legitimacy of the end (quality) is provided by the means to achieve it. The instrument, then, becomes the policy itself.

Interestingly enough the revision assumes the normative purpose as an ultimate legitimacy instance as it is "an opportunity 
to reinforce the institutional response to challenges such as widening participation, reducing dropout, improving employability etc., and to ensure that QA encourages the development of a strong quality culture and the genuine engagement of the academic community" (European Commission, 2014, p. 5).

However, given the context within which the politics of quality has evolved in and the paraphernalia of instruments enacted for its implementation, the context restricts the room for manoeuvre for actors and higher education institutions to focus on the normative goals envisaged by the political endeavour of quality.

\section{Conclusion}

In analysing European quality in higher education the distinction between politics and policies made evident the power imbalance between institutions and actors dealing with quality issues. By convening the role of normative and cognitive ideas the shift from the centrality of political values as worthy by themselves, such as 'trust', 'mobility', 'cooperation' to instrumental ideas reflecting proceduralism, was identified. Both the ESG definition in 2005 and their revision in 2015 reflect this shift in the legitimation of policies to their justification by cognitive approaches to policy-making. In line with Schmidt one might argue that the ESG are assuming the role of "recipes, guidelines, and maps for political action and serve to justify policies and programs" (Schmidt, 2008, p. 306) providing taken-for-granted assumptions on political procedures that justify evaluation of quality. By overlapping the definition of the problem of quality with its solution "the evaluation of quality is worthwhile but its justification is not that it is worthwhile in itself. It gains its points from the benefits that flow from it" (Barnett, 1994, p. 178). 
The ends/means reversal represents a configuration of political coordination where the nature of the policy is shaped by the nature of its instruments. As important as quality are the tools for its measurement and monitorisation because it is easier to take political action and furthering integration on the basis of procedures than on the basis of shared principles, values, and purposes. The analysis pointed to the fact that quality standards for EHEA are pragmatically oriented. While it is difficult to identify institutional practices indicating either the institutionalisation and/or the enactment of ESG (European University Association, 2005; Sarrico, Veiga, \& Amaral, 2013), there doubts that agencies' membership in ENQA and their registration in the EQAR might generate the level of mutual trust needed for the credibility within the EHEA. Actually, research has been pointing out that when higher education institutions deal with quality processes oriented by the ESG (Manatos, Sarrico, \& Rosa, 2014) the extent to which there are interdependencies between the intrinsic improvement of the learning experience of students and the adoption of the ESG remains to be seen.

\section{References}

Amaral, A., Tavares, O., \& Cardoso, S. (2011). Regaining Trust. Is it possible? Paper presented at the Paper presented at the VI European Quality Assurance Forum, Antwerp, 17-19 November.

Barnett, R. (1994). Power, Enlightenment and Quality Evaluation. European Journal of Education,, 29 (2), 165-179. doi:http://doi.org/10.2307/1561639 ENQA. (2005). European Standards and Guidelines. Helsinki, Finland: European Quality Association.

ENQA. (2006). Report by an ENQA review panel: Quality Assurance of Higher Education in Portugal: An Assessment of the Existing System and 
Recommendations for a Future System. Occasional Paper 10. Helsinki, Finland.

ENQA. (2015). Standards and guidelines for quality assurance in the European Higher Education Area (ESG). Yerevan.

European Commission. (2001). European Governance - $a$ White Paper. Brussels. European Commission. (2004). Report from the Commission to the European Parliament, the Council, the European Economic and Social Committee and the Committee of the Regions on the Implementation of Council Recommendation 98/561/EC of 24 September 1998 on European cooperation in quality assurance in higher education. Brussels.

European Commission. (2009). Report from the Commission to the Council, the European Parliament, the European Economic and Social Committee and the Committee of the Regions - Report on progress in quality assurance in higher education. Brussels.

European Commission. (2014). Report from the Commission to the European Parliament, the Council, the European Economic and Social Committe and the Committe of the Regions - Report on Progress in Quality Assurance in Higher Education. Brussels.

European Commission of the European Communities. (1991). Memorandum on Higher Education in the European Community. Brussels.

European University Association. (2005). Developing an internal quality culture in European universities. Brussels.

Glynos, J., \& Howarth, D. (2007). Logics of Critical Explanation in Social and Political Theory. Oxon: Routledge.

Hall, P. A., \& Taylor, R. C. R. (1996). Political Science and the Three New Institutionalisms. Political Studies, 44(5), 936-957. doi:10.1111/j.1467-9248.1996.tb00343.x

Hood, C. (2000). The art of the state - Culture, Rhetoric, and Public Management. Oxford: Oxford University Press.

Kingdom, J. (1984). Agendas, Alternatives and Public Policies. New York: Longman. Kjaer, A. (2010). Governance. Cambridge: Polity.

Kjaer, P. (2010). Between Governing and Governance: on the Emergence, function and form of Europe's Post-national constellation. Oxford: Hart Publishing. 
Laclau, E., \& Mouffe, C. (1985). Hegemony and Socialist Strategy: Towards a Radical Democratic Politics. London: Verso.

Lascoumes, P., \& Galès, P. L. (2007). Introduction: Understanding Public Policy through Its Instruments - From the Nature of Instruments to Sociologiy of Public Policy Instrumentation. Governance: An International Journal of Policy, Administration and Institutions, 20(1), 1-21.

Magalhães, A., Veiga, A., Ribeiro, F., Sousa, S., \& Santiago, R. (2013). Creating a common grammar for European higher education governance. Higher Education, 65(1), 95-112. doi:10.1007/s10734-012-9583-7

Manatos, M. J., Sarrico, C., \& Rosa, M. J. (2014). Perceptions of academics on ESG implementation in Portuguese universities. Paper presented at the EAIR 36th Annual Forum in Essen, Germany, Essen.

Mehta, J. (2011). The Varied Roles of Ideas in Politics: From "Whether" to "How". In D. Béland \& R. H. Cox (Eds.), Ideas and Politics in Social Science Research (pp. 23-46). Oxford: Oxford University Press.

Neave, G. (1994). The Politics of Quality: Developments in Higher Education in Western Europe 1992-1994. European Journal of Education, 29(2), 115-134. doi:http://doi.org/10.2307/1561636

Neave, G. (2012). The Evaluative State, Institutional Autonomy and Reengineering Higher Education in Western Europe: The Prince and His Pleasure Institutional Autonomy, the Basingstoke: Palgrave.

Phillips, L., \& Jørgensen, M. W. (2004). Discourse Analysis as Theory and Method. London: Sage.

Sarrico, C., Rosa, M. J., Teixeira, P., \& Cardoso, M. F. (2010). Assessing Quality and Evaluating Performance in Higher Education: Worlds Apart or Complementary Views? Minerva, 48, 35-54.

Sarrico, C., Veiga, A., \& Amaral, A. (2013). Quality, management and Governance in European Higher Education Institutions. Journal of European Higher Education Area, 4, 47-69.

Schmidt, V. A. (2008). Discursive Institutionalism: The Explanatory Power of Ideas and Discourse. Annual Review of Political Science, 11(1), 303-326. doi:10.1146/annurev.polisci.11.060606.135342 
Somers, M., \& Gibson, G. D. (1996). Reclaiming the Epistemological "Other": Narrative and the Social Construction of Identity. In C. Calhoun (Ed.), Social Theory and the Politics of Identity (pp. 37-99). Oxford: Blackwell Publishers.

Stoker, G., \& Marsh, D. (2010). Introduction. In D. Marsh \& G. Stoker (Eds.), Theory and Methods in Political Science (pp. 1-12). New York: Palgrave. 